\title{
Preventative Prophetic Guidance in Infection and Quarantine
}

\author{
Kabiru Goje \\ Universiti Sains Islam Malaysia, kabiru@usim.edu.my
}

\begin{abstract}
Medical treatment is one of the most important means for preventing communicable diseases in the modern time. In this situation, a person is prevented from entering a location that is infected by this disease to prevent its spread. In equal vain, the people of that location are prevented from getting out of it; weather such a person is infected or not. However, Quarantine is considered in the contemporary time as one of the human preventative mechanism from the spread of infectious diseases and the reason being that it is used in containing and controlling the risk of outbreaks. This is one of the humiliating tests from Allah the Highest on human, and shows the mightiness of His mercy. Hence, the Use of Quarantine has achieved a great significance in preventing spread of diseases because it is a primary means for combating communicable diseases in the world. Our goal and objective are to provide access to scientifically sound and culturally acceptable information on health promotion and disease prevention, to all those who need it, using the information from Prophetic Traditions. The methodology in this research to examine the concept of infection and quarantine in the light of the Prophetic traditions so that the relationship between these two concepts and the Prophetic traditions will be distinctly explained by using the data from many Islamic books, journals and articles relevant to Prophetic Islamic medicine and contemporary medicine. The result of this study revealed that the Holy Prophet (peace be upon him) was so concerned about every aspect of human life including that of health. This was yielded from prophetic traditions that infused preventive knowledge, which if humans could have made proper use of it, they would be prevented from many illness and healed others. In conclusion, the study addresses prophetic traditions that are related to preventive medicine about infection and quarantine, and support these prophetic traditions by contemporary doctors' opinions, which are attested by the fact, or are proved by experiments that accounts for non-violation of the Sharia.
\end{abstract}

Keywords: Prophetic Traditions, preventive medicine, infection and quarantine

\section{Introduction}

All praise is due to Allah, we seek His forgiveness and assistance and we seek refuge in Allah from the evil of our soul, and our wrongdoings, whoever that is guided by Allah, no one can have 
misled and whoever that is astray, no one can guide beside Allah. I bear witness that there is no god except Allah and that Muhammad PBUH is His servant and messenger. Indeed, the best of book is the Book of Allah, and the best of guidance is the guidance of prophet Muhammad PBUH, and the worst of matter is the fabrications, and all fabrications are innovation and all innovation are astray and all astray are hell fire.

Studies have shown that religion has effectively worked as a coping and prevention strategy in health-related issues. Religion has a key role in social integration and control. Religion is part of the culture or the way of life of a society, and it helps to maintain cultural traditions. Society can only survive if people share some common beliefs about right and unethical behaviour.

Religiosity relates to the influence of social referents and thus may be viewed as analogous to construct from the Theory of Planned Behaviour. Linking health messages to religious or spiritual themes, or using religious elements on messages, may be appropriate motivational strategies. This can be done through manipulation of social effects such as linking health behaviours to specific religious commandments or using the norms of the faith as a source of positive or negative sanctions. As proved by Campbell, emphasizing personal feelings of religious pride or shame can invoke attitudes towards health practices. Eckersley argued that psychological literature on health and religion suggests that the benefits to wellbeing flow from the social support, existential meaning, sense of purpose, coherent belief system and moral code that religion provides.

Therefore, the modifiable lifestyle behaviours, physical inactivity, poor sanitation and hygiene can result in the development of communicable, non-communicable and chronic diseases. According to the UN Chronicle Magazine today, foodborne and chronic diseases are a major global public health problem. In 2005, the World Health Organization (WHO) estimated that 61 per cent of all deaths and 49 per cent of the global burden of disease were attributable to chronic diseases. By 2030, the proportion of total global deaths due to chronic diseases is expected to increase to 70 per cent and the global burden of disease to 56 per cent. Religion has shown to play a significant 
role on shaping people's behaviour, attitude, and mode of communication, interaction and lifestyle.

However, Quarantine is considered in the contemporary time as one of the human preventative mechanism from the spread of infectious diseases and the reason being that it is used in containing and controlling the risk of outbreaks. This is one of the humiliating tests from Allah the Highest on human, and shows the mightiness of His mercy. Hence, the Use of Quarantine has achieved a great significance in preventing spread of diseases because it is a primary means for combating communicable diseases in the world. The prophet SAW explains in many of his traditions in clear terms; the fundamentals of medical treatment and Quarantine, by refusing people from entering the location that is infected by the diseases and also refuse the people of that location from getting out, rather that is done as a means to avoid crawling from grievous sins which serves as martyrdom to the patient once as it is said that it is not permissible to marry an infected person. Rather, there is a legal provision for such to take preventative measures to avoid calamity. This is done by avoiding the infected victims with the concerns of spread and infecting other healthy places by the permission of Allah.

So, this study addresses prophetic traditions that are related to preventive medicine about infection and quarantine, and support these prophetic traditions by contemporary doctors' opinions, which are attested by the fact, or are proved by experiments that accounts for non-violation of the Sharia.

\section{The Meaning of Quarantine According to the Islamic Scholars}

The meaning of Quarantine in Arabic language is prevention to act; the judge prevented the insolvent person from acting on his wealth when he is declared bankrupt. It is said that for the holy house is prevention because there are prevented there in and that is the meaning of a Quarantined substance. And from the tradition of Aisha and Ibn Zubayr, (Indeed I have decided to declare her prevented) ${ }^{1}$.

Ibn Sidah said: it is derived from the root word, to quarantine, quarantining, that is to prevent from acting. Not quarantine from,

Aḥmad bin Fāris bin Zakariyyā al-Quzwayn̄̄ al-Rāzī, Maqāyis al-Lughah (Dār al-Fikr, 1979), 105. 
that is no prevention from and no repulsion. ${ }^{2}$ Therefore the meaning of Quarantine is preventing the healthy from mixing with the infected victims ${ }^{3}$.

\section{The definition of Quarantine According to the Medical Doctors}

This is the process of preventing the infected patient from mixing with the general healthy people. This is done through quarantining the diseases and infection in a particular place, separately and preventing people from mixing with them except those that are necessarily required to be with them among the doctors and nurses with specific medical provision and such places are called Quarantined place, and it is the place specifically made for the infected patient to reside throughout the period of their medical treatment. ${ }^{4}$

Usually in medical quarantine, the infected patient is placed under strict medical observation and treatment until the end of the care, and this is the period between the emergent of microorganism symptom in the body, and this could be short or long period depending on one disease to the other, and at the end of the Quarantine period, it either exposes the infection on the quarantined body so it will be cured as it usually cure other disease or it does not show any symptom and such require a medical certification that such a person is free from the disease and is consequently allow out of the medical quarantine ${ }^{5}$

\section{Medical Quarantine from the Perspective of Prophetic Sunnah}

Medical quarantine is considered as one of the most important means of preventing spread of communicable diseases, as a condition, it prevent any person from entering the affected the diseases, and mixing up with the victims, and prevent any person

2 Muḥammad bin 'Abd al-Razzāq al-Ḥusayn̄̄ Azabaydī, Tāj al-'Arūs min Jawāhir al-Qāmūs (n.p.: Dār al-Hidayah, n.d.), 10.

3 Șāliḥ 'Abd al-Qawiy al-Sanban̄̄, Al-'I'jāz al-'Ilmī fì al-Tỉb al-Wiqā' '̄ (n.p.: Idris 'Abd al-Qawiy, Al-eeman university, n.d.), 80.

4 Ḥasan bin Aḥmad bin Ḥasan al-Faky, Ahkām al-Adawiyyah fì al-Sharī‘ah alIslāmiyyah (n.p: Dār al-Manhaj Bookshop for publication and distribution, n.d.), 128.

5 Al-Faky, Ahkuām al-Adawiyyah fì al-Sharī'ah al-Islāmiyyah 130. 
from that location from getting out, weather infected is ascertained or not ${ }^{6}$.

The prophet PBUH has specifically mentioned several fundamental principles of medical Quarantine in a clear term, so preventing people from entering the places that are infected by the outbreak and preventing the people of that location from getting out, rather that is made as crawling from one of the grievous sin which serve as martyrdom to the infected patients, and from this hadith we can draw the following justification for the medical Quarantine from the prophetic sunnah as follows:

1. 'A' ishah reported the prophet pbuh to have said: (My people will not be tested except with abuse and communicable diseases, we said oh prophet of Allah pbuh: we know abuse, and what of the communicable diseases, a gland such as the gland of the camel, whoever stay therein is a martyr and whoever try to escape is like trying to escape from crawling) $)^{7}$.

2. Abu Hurayrah reported the Prophet PBUH said: ((The sick person is not mixed with healthy) $)^{8}$.

3. Ibn 'Abbas may Allah be pleased with both, he reported the prophet PBUH to have said: ((Do not keep looking at a leprous person) $)^{9}$.

4. 'Amr bin al-Sharid bin al-Suwadi al-Shafi'‘̄, who said: ((Among the missionaries of Saqeef was a leprous man, so the prophet pbuh sent a message to him that his covenant is binding that he can now return to his abode) $)^{10}$.

5. From Usāmah bin Zayd, who reported the prophet to have said: ((If you heard of any communicable disease in any place, do not go there! and if it occurred in a place where you are, do not get out from therein!) $)^{11}$.

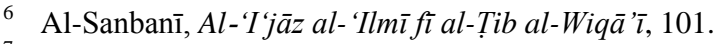

7 Aḥmad bin 'Alī bin al-Mathunā bin Yahyā bin 'Īsā bin Hilāl al-Tamīmī, Musnad Abū Ya 'lā (Damascus: Dār al-Ma'mūn li al-Turath, 1984) 7:379, Hadith No: 4408.

8 Muḥammad bin Ismā‘îl al-Bukhārī, Al-Jāmi ‘ al-Ṣaḥ̄ḥ al-Mukhtaṣar (Beirut: Dār al-Ibn Kathīr, 3rd edition, 1987), 5,2177, hadith No. 5437.

9 Muhammad bin Yazīd Abū 'Abd Allāh bin Majah al-Qazwin̄̄, Sunan Ibn Majāh (Dār al-Ihya' al-Kutub al-'Arabiyyah, 2010), 2:1172, hadith no.3543.

${ }^{10}$ Muslim bin al-Hajjaj al-Qushayrī al-Naysabūrī, Șaḥ̄ḥ Muslim (Beirut: Dār alIhya' li al-Turath al-'Arabiyyah, 2010), 4: 1752.

11 Al-Bukhārī, Al-Jāmi ‘ al-Ṣaḥ̄ḥ al-Mukhtaṣar, 5:2163, hadith No. 5396. 
6. From ' $\bar{A}$ 'ishah, the wife of the prophet pbuh said: I asked the prophet PBUH about the communicable disease and he told that it is a punishment from Allah which He afflict with whomever he wishes, and Allah made it as mercy for the believers, there is no among men whom where afflicted by the communicable diseases yet were patient knowing fully well that nothing will afflict him except what Allah has decreed for him) $)^{12}$.

7. From Usāmah bin Zayd who reported the prophet pbuh to have mentioned about communicable diseases)) this is one of the remaining calamity and punishment that is descend on the children of Israelite, if it happens in a land and you are therein, do not get out! And if it descends on a place where you are not present, do not go therein!) $)^{13}$.

However, these prophetic teachings are evidences to show that whenever there is an outbreak of communicable diseases in a particular place, it is not permissible to enter therein with the fair of not exposing self into danger of been infected by the outbreak and the infected victims are disallowed from getting out from the place with the fair of spreading the diseases to others. Equally the sick is not placed upon the healthy until to avoid the inconveniences from it in accordance with the will and destiny from Allah. This is the meaning of medical Quarantine. AlQurtubi, may Allah be pleased with him said in one of his reported commentaries of an Hadith of Sa'ad, ${ }^{14}$ Which indicates the fact that it is an obligation on human being to prevent misfortunes before its occurrence and to avoid certain treats before its attack, also it is an obligation on him to be patient and avoid fair after its occurrence because the prophet pbuh has forbidden whoever that is not in the land where calamity occur to enter therein if an outbreak occurs in it. And forbid whoever that is therein from getting out from the outbreak as a means of escaping from it. However, it is also an obligatory to accept the legal rulings in

12 Al-Bukhārī, Al-Jāmi ‘ al-Șaḥịh al-Mukhtașar, 3:1281, Hadith no. 3287.

13 Muhammad bin 'Īsā al-Tirmidhī bin Sawrah bin Mūsā al-Ḍaḥhāk, Sunan alTirmidhī (Beirut: Dār al-Iḥya' li al-Turath 'Arabiy, n.d.), 3:378, hadith no.1065, \& Ahmad bin Shu'ayb bin 'Alī al-Kharasānī al-Nasā'̄̄, Al-Sunan alKubrā (Beirut: Dār al-Kutub al-'Ilmiyyah, 1991), 4:362, hadith no.7524.

14 That is a hadith reported by Usamah on Virus Disease that was mentioned earlier because the story is between Saad and Usamah, may Allah be pleased with them all. 
exclusive nature, such as the case of communicable diseases. And this is the basic concept of the statement of the prophet pbuh thus: Do not wish to meet your enemy and seek peace always but if you meet it, then be patient! After this, al-Qurtubi may Allah be pleased with him said: this statement is sound from the chapter which summarizes the words of the prophet pbuh and upon which he taught his companions until he said: A man cannot avoid whatever Allah has decreed for him rather Allah commanded us to be mindful and careful of treat and destructions, and seeking a wide prevention from the hateful. ${ }^{15}$

Ibn Qayyīm may Allah be pleased with him said: the prophet pbuh has gathered the community of believers on his path by avoiding any places where there is diseases outbreak and forbid people from getting out therein after which the outbreak had occurred, because entering the land which the outbreak occurred is exposing one's self to danger and subjecting himself to be infected. And this is exposing oneself to danger which is against Islamic law and logical reasoning, rather avoid entrance in it is a means of protection which Allah the most Glorified has guided man, and this is protection from being tied down or harmful outbreak. ${ }^{16}$ Hence, these afore mentioned statements by the scholars about the hadith are clear indications on the juristic justification of medical quarantine, and it is not permissible for anyone to expose his life to any infectious calamity. Also, it is forbidden for everyone therein the outbreak to get out because of the fair of spreading the diseases to the healthy people.

However, it is equally manifested in this hadith the miracles of the prophet pbuh by forbidden an exit from a person residing in a land where is a calamity even if he has not been infected, since when people are disallowed entrance to a place where there is calamity might be clearly understood but forbidding whoever is inside the place where such calamity occurred from getting out even if he is seems healthy. The legal logical reason behind this

15 Abū 'Abd Allāh Aḥmad bin Abū Bakr bin Faraj al-Anșarī al-Qurțubī, AlJāmi’ al-Aḥkām al-Qurān (Saudi Arabia: Dār al-'Alam al-Kutub, 2003), 3:232-233.

16 Muhammad bin Abī Bakr bin Ayyūb bin Sa'ad al-Zur'̄̄ al-Shahīr bi Ibn Qayyim, Zād al-Ma'ād fì hudā khayr al-'Ibād (Beirut: Muassah al-Risālah, 1986).4:39 
seems unclear, rather logical reasoning also reject an healthy person that reside in the place of calamity to escape to other safe place, so as not to be affected by the infection, though the legal reasons behind this was not known until the late generation with emergence of scientific and medical development, and the modern medicine has established that an healthy person in a location where there is calamity could either be a carrier (victim) of microorganism and many of the infections that affect people in their body through micro-organism are not automatically seen as ill. And there are many person that are carriers of killer diseases yet its not showing any physical symptoms of it such as, Schizophrenia fever, typhoid fever, dysentery, Basile, Tuberculosis, cholera and other communicable diseases are infections which may have affected many people without showing any sign of physical symptoms in them, rather an escaping person might be physically healthy but still transfer the infections to others healthy people, and there is a treatment period which is a specific period that the symptoms of the disease is expected to show since it enters the microbe and grow over time until it develops, so during this period, it seems not to a person that he is healthy from any sickness but after a long or short period of time the particular microbes of infection carried will appear in the body based on the type of sickness and the kind of microbes infection. For example, the incubation period for the flu is a day or two, while the incubation period of inflammation of the liver virus could be as far as six months, equally the microbe of Tuberculosis could be hidden in the body for many years without moving rather it does not goes on after that period to be rampant in the body, so who is that person that bestow Muhammad pbuh all these things wisdom? And who taught him these facts, and he is even unlettered person that cannot read nor write? indeed it is the science of the Lord, the spiritual revelation, that came before all these sciences and knowledge, in order to establish this religion as evidence upon human being in all places and at all times so as to be an argument over the whole world, though some people will perish with the evidences while some will be saved with this evidence. May Allah peace and blessing be upon the final messenger and the leader of prophets ${ }^{17}$.

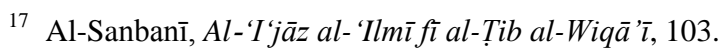




\section{Literary and Technical Definition of Infection}

Infection in Arabic word (Al adwiy) it is derived from the word enemies that is; to show enmity and war to others, or to accept enmity from others. The root meaning of Al Adwiy is when one who show opposition because of exceeding bound, for example when we say: the Persians show opposition between the two hunting and between the two men when they are continuously stab twice and it is also said to mean a person infect another in his character or from it reason or experiment when he exceeds bound in character or from the first person to the second ${ }^{18}$.

\section{Technical Definition of Infection According Medical Experts}

It is the transfer of disease from the sick to the healthy through different mediums such as; breathing, touching and blood. ${ }^{19}$

The researcher viewed that this definition is the most popular meaning but there are other views from other medical doctors such as Abdur-Rahman Jamal, who opined that it is incomprehensive if understand sickness is not as a result of mere transfer of the bacterium carrier from one person to another, rather the bacterium will definitely penetrates the anti-bodies and the barriers that is created to block those invasions, which could be shown for example as skin mucous membranes and others. Also, these bacterium that causes sickness will cause injury and weakness to the body until it can cause sickness, and this is what is refers to as minimum Nausea dose, therefore the proper definition of Infection is: transfer of bacterium and Pathogenic microorganisms whereby concentrating above the Minimum nausea dose by penetrating the anti-bodies and lead to its internal organs or deep places within the body. It destroys and exposed the body to danger and this is the final reaction called inflammation ${ }^{20}$.

18 Abū Manșūr Muḥammad bin Aḥmad al-Azharī, Tahdhīb al-Lughah (Beirut: Dār al-Iḥya' al-Turath al-'Arabī, 2001), 3:73, and Ismā‘̄il bin Hiimād alJawharī, Tāj al-Lughah wa Sihḥaḥ al-'Arabiyyah (Beirut: Dār al-'Ilmī li almalāyīn, 1990), 7:271.

19 Al-Faky, Ahkām al-Adawiyyah fì al-Sharī'ah al-Islāmiyyah,135.

20 Al-Sanbanī, Al-'T'jāz al-'Ilmì fì al-Tib al-Wiqū' '̄i, 138. 


\section{The Legal Ruling on Infection}

There have several reported legacies from the prophet pbuh concerning infection, some of it confirms infection while others negate it, and these legacies are as follows:

\section{The Hadiths that Confirm Infection:}

1. From Abū Hurayrah may Allah be pleased with him, who reported the prophet pbuh to have said: ((No Infection .....and to escape from the leper as you escape from the lion) $)^{21}$.

2. 'Amr bin al-Sharid reported from his father al-Sharid bin Suwayd al-Thaqafì, may Allah be pleased with him who reported the prophet pbuh to have said; ((There was a man among the missionaries of thaqif who is leprous, so the prophet pbuh sent a message to him that his homage has been accepted so he should return to his abode) $)^{22}$.

3. Abū Hurayrah reported the prophet pbuh to have said: ((Do not bring the sick person together with the healthy) $)^{23}$.

4. Ibn 'Abbās may Allah pleased with both reported the prophet pbuh to have said: ((Do not keep on looking at the lepers) $)^{24}$.

\section{The Hadiths that Negate Infection:}

1. Abū Hurayrah reported the prophet pbuh to have said: ((There is neither Infection nor virus of yellow fever, nor vermin) $)^{25}$.

2. From 'Abd Allāh ibn 'Umar, has reported the prophet pbuh said: ((There is neither transfer of infection nor virus from birds and there is pessimism in divorce of three count, in devilish household and animals) $)^{26}$.

3. From Anas bin Malik may Allah be pleased with him who reported the prophet pbuh to have said: ((There is neither transfer of infection nor from flow of birds and being optimistic for good really impressed me, ) ) ${ }^{27}$

4. From Jābir bin 'Abd Allāh may Allah be pleased with bothwho reported the prophet pbuh to have said: ((There is neither

${ }^{21}$ Al-Bukhārī, Al-Jāmi ‘ al-Șah̄ḥ al-Mukhtașar, 5 :2158, Hadith no. 8,538.

22 Muslim, Șaḥ̄h Muslim, 4: 1752.

23 Al-Bukhārī, Al-Jāmi ‘ al-Șaḥịh al-Mukhtașar, 2177. Hadith no. 5437.

24 Ibn Mājah, Sunan Ibn Mājah, 2:1172. Hadith no. 3543

25 Al-Bukhārī, Al-Jāmi ‘ al-Șahīh al-Mukhtașar, 5:2161. Hadith no. 5387.

${ }^{26}$ Naratted by al-Bukhārī, Șaḥịh al-Bukhārī, 5: 2171, hadith no. 5421.

27 Naratted by by al-Bukhārī, Șahīh al-Bukhārī, 5:2171, hadith no. 5424. 
transfer of infection nor from flow of birds nor devilish notations) $)^{28}$

\section{The Most Probable View about Infection:}

The facts mentioned above are the reported views on infection, and it appears to be conflicting where some indicate negation while others established it, and this is away from one who has pessimistic because of safety from infection. Meanwhile, before mentioning the view of scholars on the focus and purpose of these hadith, it is pertinent to know that there is no contradiction between the sound hadiths of the prophet pbuh, so if there seems to be any contradiction, it is either that one of the two hadith are not from the teachings of the prophets pbuh. Many of the transmitters of the hadith have mistakenly considered it to be sound and an established teaching so this confirmation is in itself a mistake, or either of the hadith is an abrogation of the other if it is a situation where abrogation could occur, or there could have been a mistake from the listening and comprehension of the transmitter, not exactly the word of the prophet pbuh, hence, there is possibility of these three indications. For this reason, it is not possible to have two evidences proven to be correct, directly clear in indication and yet one abrogates the other in an explicit and clear form such that it makes impossible to combine both as probable in certain situations. Therefore, the statement that there are contradictions from the hadith of the prophet pbuh; could either be that such people do not understand the science of the hadith, such that the reader could not distinguish between the sound and weak one. So, these people might only be showing contradictions in hadith without basis or that a hadith contradict other by inventing a subject matter. This could either be that such a person do not understand the position and mechanism of Islamic jurisprudence from the real intent of the text, or the two clear, direct and sound hadith are conflicting in all indications and none of them is acting as abrogation to the other, so this do not occur in reality. ${ }^{29}$ Therefore Imam ibn Khuzaimah says according al-Suyuti in his book called Tadrib al-Rawi: "I do not know any two

\footnotetext{
28 Muslim, Sahịh Muslim, 4:1744. Hadith no. 2222.

29 Al-Faky, Aḥkām al-Adawiyyah fì al-Sharī'ah al-Islāmiyyah, 138.
} 
conflicting hadith, so whoever has any should endeavour to show me so that I can make concord between it" ${ }^{\prime 30}$.

Having these as a background, the researcher therefore asserts that there are neither confusion nor contradiction between the hadiths of infection because it is possible to make combination with both of them has confirmed by some scholars while other scholars has thread the path of abrogation between the two hadiths by saying: That the hadith that abrogate infection is abrogated and the hadith that confirm infection is the abrogation, and this statement is been ascribed to Qadi 'Iyad - has it is reported from him by al-hafiz Ibn Ḥajār al-'Asqalānī in his book Fath al-Bārī, in accordance to opinion of Umar bin al-Khattab and group of Salafs ${ }^{31}$, but this position has been opposed by Issa bn Dinar from Mālik school of thought has reported by al-hafiz Ibn Hajar al'Asqalānī in his book Fath al-Bārī, that the sound statement and position which majority of scholars tend toward is that there is no abrogation, rather it is obligatory to do combination and make concord between the two hadiths ${ }^{32}$, while some scholars has thread the path of preferential judgement, by preferring the hadith that negate infection and consider the hadith that confirm infection as uncommon, but this position is not correct because the hadith that confirm infection are entirely sound without any obscurity as they are reported in the two sound books (al-Sahīhāyn), so Ibn Hajar al'Asqalani in his book Fath al-Bari, responded against them by saying: "The answers is that the path to preference judgement does not occur in it except with the excuse of combination which is possible and better",33.

He therefore mentioned six patterns of combination, but the closest of them which is mostly accepted by the scholars is that the meaning of negation of infection is simply negation of the belief of the ignorant people that there are certain sicknesses such as scabies infection which can attack human without resting it occurrence with the permission of Allah, because this I a kind of

30 'Abd al-Rahman Abī Bakr al-Suūṭ̂̄, Tadrīb al-Rāwī fì Sharh Taqrīb alNawāwī (Riyadh: al-Riyadh al-Hadīth Bookshop,n.d.), 2:196.

31 Aḥmad bin 'Alī bin Hajar al-'Asqalān̄̄, Fatḥ al-Bārī Sharh al-Bukhārī (Beirut: Dār al-Ma'rīfah, 1957), 10:159.

32 Ibn Hajar, Fath al-Bārī Sharḥ al-Bukhārī, 10:159.

33 Ibn Ḥajar, Fatḥ al-Bārī Sharh al-Bukhārī, 10:159. 
Shirk (associating partners with Allah), unlike the hadith that refers to it confirmation means that: it is not permitted to belief in infection but it provide that he can give certain reasons for its bad occurrence, and this is far from the reality of whoever is attacked by the infection by transferring it to the healthy ones with the permission of Allah such as scabies and leprosy. For this reason, Ibn Hajar said: The fifth pattern: That the meaning of negating infection is that something cannot transfer itself by nature as usually assumed by the people of ignorant that diseases can transfer itself without the permission of Allah, so the prophet pbuh is negating this assumption by eating with the leprous person in order to clarify that Allah is the only one who cause sickness and heal, and forbid them from associating with this in order to explain that these are some of the reasons and symptoms which Allah made as course toward it occurrence, and eventually the symptoms is established but according to the nature it does not occur nor affect except with the permission of Allah and if Allah wills make it occur and infect people". The Imam mentioned that this statement is the opinion of majority of the Shafi 'iyyah school of thought. ${ }^{34}$

Al-Nawawi said: the means of combination between hadith that negate infection means the negation of the belief by the people of ignorant who assume and belief that sickness and calamity can transfer by its nature without the permission and power of Allah, but the hadith that says: " the sick people should not be mixed with the healthy ones" is an advise to be careful of mixing with people that has medical issues which might transfer with the permission and mighty of Allah, so the negation in the first hadith with the nature of infection which does not negate the occurrence of infection in that situation with the mighty and permission of Allah which He gave advise in the second to be careful and cautious about whatever difficulty that happened to man is with the permission will and mighty of Allah. This is what the researcher mentioned in accordance with the soundness of the two hadith in which there exist the correctness of the position of most scholars which many people prefer. ${ }^{35}$

${ }^{34}$ Ibn Hajar, Fath al-Bārī Sharḥ al-Bukhārī, 10: 160

35 Yahyyā bin Sharaf al-Nawāwī, Al-Manhaj Sharh Șaḥịh Muslim bin Hajjaj (Beirut: Dār Ihyā' al-Turath al-'Arab̄i, n.d), 14:214. 
Ibn Qayyim may Allah be pleased with him said: "My position on these two hadith in another vain encompasses the establishment of purposes, rulings and negation of polytheism and false belief and the occurrence of negation and establishment in it perspective so the generality of the people usually confirm infection in their school of thought and oppose false polytheism as said by the Astrologers on the effect of the stars in this world of how it ascends and descend has been mentioned"36. Till the end of his statement- may Allah be pleased with him.

This is the course upon which al-Nawawi, and ibn Qayim and the majority of Shafi'iyyah which are group of classical and contemporary scholars based their argument and this is exactly the right and correct position because it combines all the various facts that there is neither problem nor conflict in them. Therefore, alNawawi earlier said: This is the correct view in accordance with the opinion of the majority of scholars which most preferable ${ }^{37}$.

\section{Conclusion}

This study has focused on critical issues that is related to infection and medical Quarantine in the light of prophetic Sunnah as derived from the al-Quran and Sunnah and it focuses on the gathering information that relates with the topic of the research, and the researcher tried to combine revealed knowledge and human sciences, and after which useful result where reached among which are as follows:

1. That the prophet pbuh- took human life with upmost importance such as his perspective on infection and medical quarantine whereby some hadith are reported on it which has some medical guidance and counselling in the situation of infection and medical Quarantine, and with this, the researcher has been able to achieve the aim of the study- by the mercy of Allah- the primary goal in this study is to combine the revealed knowledge and human sciences.

2. The most probable opinion from the definitions of infection is the transfer of Microorganisms that course sickness, by close examination; it will over power the minimum nausea dose,

${ }^{36}$ Muḥammad bin Abī Bakr bin Qayyīm al-Jawziyyah, Miftāḥ al-Sa'adah (Beirut: Dār al-Kutub al-'Ilmiyyah, n.d.), 2:269.

37 Al-Faky, Ahkām al-Adawiyyah fì al-Sharī'ah al-Islāmiyyah, 139. 
whereby it will penetrate the anti-bodies and reached it inner tissues, or the inner organs in the body such as the blood, fluid, and will affect the reaction of the body; dominate and destroying it and this is the final reaction which is known as inflammation.

3 . The most probable from the hadith of infection is the combination between the two, because the hadith of negation means negation of what is usually assumed in the period of ignorant by presuming and believing that sickness and pessimism occurred by itself and not from permission of Allah, and the established hadith indicates that it is not permissible to assume and belief as such but it is allowed to ascribe reasons and symptoms to the occurrence of calamity, by distancing the victims with the fair of transfer of infection to the healthy one by the permission of Allah. In order that devil will not whisper into him from what afflicted him because of the infection.

4. Medical Quarantine is considered as one of the most important means of preventing spread of communicable diseases in this modern time, and the hadith of the prophet pbuh has established it permissibility.

\section{References}

Al Tamīmī Aḥmad bin 'Alī bin al-Mathunā bin Yahyā bin 'Īsā bin Hilāl. Musnad Abū Ya'lā. Damascus: Dār al-Ma'mūn li alTurath, 1984.

Al-'Asqalānī, Aḥmad bin 'Alī bin Hajar. Fath al-Bārī Sharh alBukhārī. Beirut: Dār al-Ma'rīfah, 1957.

Al-Azharī, Abū Manșūr Muḥammad bin Aḥmad. Tahdhīb alLughah. Beirut: Dār al-Ihyya' al-Turath al-'Arabī, 2001.

Al-Bukhārī, Muḥammad bin Ismā'īl. Al-Jāmi' al-Ṣaḥịh alMukhtașar. Beirut: Dār al-Ibn Kathīr, 3rd edition, 1987.

Al-Faky, Hasan bin Aḥmad bin Hasan. Ahkām al-Adawiyyah fì alSharī'ah al-Islāmiyyah. N.p: Dār al-Manhaj Bookshop for publication and distribution, n.d.

Al-Jawharī, Ismā‘îl bin Himād. Tāj al-Lughah wa Sihhah al'Arabiyyah. Beirut: Dār al-'Ilmī li al-malāyīn, 1990.

Al-Nasā’̄̄, Ahmad bin Shu'ayb bin 'Alī al-Kharasānī. Al-Sunan alKubrā. Beirut: Dār al-Kutub al-'Ilmiyyah, 1991.

Al-Nawāwī, Yahyyā bin Sharaf. Al-Manhaj Sharh Șaḥīh Muslim bin Hajjaj. Beirut: Dār Ihyā' al-Turath al-'Arabī, n.d. 
Al-Naysabūrī, Muslim bin al-Hajjaj al-Qushayrī. Sahịh Muslim. Beirut: Dār al-Ihya' li al-Turath al-'Arabiyyah, 2010.

Al-Qurțubī. Abū 'Abd Allāh Aḥmad bin Abū Bakr bin Faraj alAnșarī. Al-Jāmi’ al-Aḥkām al-Qurān. Saudi Arabia: Dār al'Alam al-Kutub, 2003.

Al-Rāzī, Aḥmad bin Fāris bin Zakariyyā al-Quzwaynī. Maqāyis al-Lughah. Dār al-Fikr, 1979.

Al-Sanbanī, Șālih 'Abd al-Qawiy. Al-'I'jāz al-'Ilmī fì al-Tib alWiqā '̄. N.p.: Idris 'Abd al-Qawiy, Al-eeman university, n.d.

Al-Suyūțī, 'Abd al-Rahman Abī Bakr. Tadrīb al-Rāwī fì Sharh Taqrīb al-Nawāwī. Riyadh: al-Riyadh al-Hadīth Bookshop, n.d.

Al-Tirmidhī, Muḥammad bin 'Īsā al-Tirmidhī bin Sawrah bin Mūsā al-Ḍaḥhāk. Sunan al-Tirmidhī. Beirut: Dār al-Iḥya’ li alTurath 'Arabiy, n.d.

Azabaydī, Muḥammad bin 'Abd al-Razzāq al-Husaynī. Tāj al'Arūs min Jawāhir al-Qāmūs. N.p.: Dār al-Hidayah, n.d. 10.

Ibn Majah, Muḥammad bin Yazīd Abū 'Abd Allāh al-Qazwin̄̄, Sunan Ibn Majāh. Dār al-Iḥya’ al-Kutub al-'Arabiyyah, 2010.

Ibn Qayyīm al-Jawziyyah, Muḥammad bin Abī Bakr. Miftāḥ Dār al-Sa 'adah. Beirut: Dār al-Kutub al-'Ilmiyyah, n.d.

Ibn Qayyim, Muhammad bin Abī Bakr bin Ayyūb bin Sa'ad alZur'ī. Zād al-Ma' ād fì Hudā khayr al-'Ibād. Beirut: Muassah al-Risālah, 1986. 